\title{
Somatic embryogenesis and the effect of particle bombardment on banana Maçã regeneration
}

\author{
Laureen Michelle Houllou-Kido(1), Ederson Akio Kido(1), Maria Cristina Falco(2), Márcio de Castro Silva Filho(3),

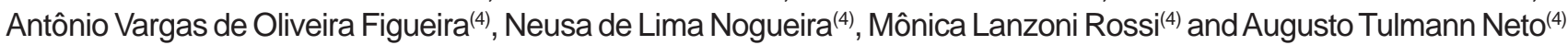 \\ (1)Universidade Federal de Pernambuco, Av. Prof. Moraes Rêgo, s/no, CEP 50670-920 Recife, PE, Brazil. E-mail: laureenhk@yahoo.com, \\ eakido@yahoo.com (2)Centro de Tecnologia Copersucar, Fazenda Santo Antônio, Caixa Postal 162, CEP 13400-970 Piracicaba, SP, Brazil. \\ (3)Universidade de São Paulo (USP), Escola Superior de Agricultura Luiz de Queiroz, Caixa Postal 83, CEP 13400-970 Piracicaba, SP, Brazil. \\ E-mail: mdcsilva@esalq.usp.br (4)USP, Centro de Energia Nuclear na Agricultura, Caixa Postal 96, CEP 13400-970 Piracicaba, SP, Brazil. E-mail: \\ tulmannneto@cena.usp.br
}

\begin{abstract}
A plant regeneration method with cell suspension cultures of banana, and the effect of biobalistic on regeneration potential are described in this report. Somatic embryos of banana were obtained from indirect embryogenesis of male inflorescence of banana cultivar Maçã (AAB group). Part of the calluses formed (40\%) showed embryogenic characteristics (nonfriable, compact and yellow color). The cell suspension, originated from embryogenic calluses, contained clusters of small tightly packed cells with dense cytoplasms, relatively large nuclei and very dense nucleoli. After four months of culture, somatic embryos started to regenerate. The maximum number of regenerated plants was observed between 45 and 60 days after embryo formation. In the first experiment, 401 plants were regenerated from approximately $10 \mathrm{~mL}$ of packed cells. In the second experiment, 399 plants were regenerated from a cell suspension six months older than that of the first experiment. Cell transformation using particle bombardment with three different plasmid constructions, containing the uid-A gene, resulted in a strong GUS expression five days after bombardment; however, plant regeneration from bombarded cells was much lower than nonbombarded ones.
\end{abstract}

Index terms: Musa, cell suspension, callus, somatic differentiation, biobalistic.

\section{Embriogênese somática e o efeito do bombardeamento de partículas na regeneração de banana cv. Maçã}

\begin{abstract}
Resumo - Neste trabalho é descrito um método de regeneração de plantas, a partir de células de bananeira, em suspensão, e o efeito da biobalística no potencial regenerativo. Embriões somáticos foram obtidos de inflorescências masculinas de bananeira cv. Maçã (grupo AAB) por meio de embriogênese indireta. Parte dos calos (40\%) apresentou características embriogênicas (não-friáveis, compactas e amareladas). Suspensões celulares obtidas desses calos continham pequenas massas celulares, com citoplasmas ricos em grânulos de amido, núcleos grandes e nucléolos densos. Após quatro meses, embriões somáticos começaram a se desenvolver. O número máximo de plantas regeneradas ocorreu 45-60 dias após a formação dos embriões. No primeiro experimento foram regeneradas 401 plantas. No segundo, 399 plantas foram obtidas de uma suspensão celular 6 meses mais velha do que a do primeiro experimento. Transformações celulares com uma das três construções plasmidiais utilizadas, que continham o gene uid-A, resultaram em fortes sinais de expressão cinco dias após as transformações; todavia, o número de plantas regeneradas foi muito menor do que o observado no material não bombardeado.
\end{abstract}

Termos para indexação: Musa, suspensão celular, calos, diferenciação somática, biobalística.

\section{Introduction}

More than 58 million tons of bananas and 30 million tons of plantains are produced worldwide (FAO, 2001). India is the largest producer of bananas (11 million tons), and Uganda is the largest producer of plantains (9 million tons). Nearly half of the world banana production is cultivated in Asia, while almost $75 \%$ of the world's plantains are cultivated in Africa. The world average yield is 15 tons ha $^{-1}$ for banana and about 6 tons ha- ${ }^{-1}$ for plantain. Banana is a staple food for nearly 400 million people throughout the developing world (Sasson, 1997). The main impediment for banana production is associated with fungal and viral diseases. 
The development of new varieties by sexual crossing in banana is extremely difficult, because only few diploid clones produce viable pollen to use in crosses with female-fertile triploids for the production of a few tetraploid seeds (Shepherd, 1987). The major part of germplasm from the commercially most important clones (group $\mathrm{AAA}, \mathrm{AAB}$ and $\mathrm{ABB}$ ) is excluded from sexual breeding, because it is triploid and entirely male and female sterile (Novak et al., 1989).

In fact, the application of classical methods of breeding, for both disease and pest resistance, has resulted in limited success for banana. The integration of genetic engineering into breeding programs may provide powerful tools to overcome this limitation, by introducing specific genetic changes that can be utilized in banana improvement within a short period of time (Khalil et al., 2002). However, these applications require reliable plant callus or cell suspension regeneration protocols for banana.

Immature male inflorescences have been used to initiate cultures of several banana and plantain cultivars (Escalant et al., 1994; Sagi et al., 1995; Côte et al., 1996; Navarro et al., 1997). Escalant et al. (1994) suggested that somatic embryos are probably of unicellular origin. This method has the potential to produce nonchimeric plants, making it an excellent option for nonconventional breeding programs. Somatic embryogenesis techniques in the genus Musa are aimed at developing new, highperformance micropropagation techniques and a cell regeneration system useful for genetic improvement (Côte et al., 1996). In order to help breeding projects, the cell culture could be associated to mutation induction, transformation processes (biobalistic or Agrobacterium systems) or selection of material from somaclonal variation. Unlike meristem cultures, a large number of cells can be treated using cell suspension as explant. Published protocols for regeneration of banana plants from cell suspension have mainly focused on exporttype "Cavendish" (genome AAA). Therefore, the development of an efficient callus regeneration method for important Brazilian economic banana cultivars, such as cv. Maçã (Silk type, AAB group), could offer an alternative for crop improvement.

This research aimed at developing a plant regeneration method from callus, derived from cell suspension cultures from male inflorescences of banana cv. Maçã, and to study the effect of transformation, using microparticle bombardment, in the embryogenic callus regeneration potential.

\section{Material and Methods}

The initial plant material consisted of Musa spp. (AAB group) cv. Maçã male buds. For callus induction, immature male flowers were isolated and cultured in Petri dishes at $28^{\circ} \mathrm{C} \pm 2^{\circ} \mathrm{C}$ in darkness, in embryogenic medium (ME1) consisting of MS salts (Murashigue \& Skoog, 1962), supplemented with $8.3 \mathrm{mg} \mathrm{L}^{-1}$ of picloran and Phytagel $0.2 \%$ at $\mathrm{pH}$ 6.1. Part of the calluses formed were transferred to the liquid ME2 medium, containing modified MS salts ( $1 / 2$ macro nutrients; $1 / 2 \mathrm{NH}_{4} \mathrm{NO}_{3}$; $1 / 2 \mathrm{CaCl}_{2}$; and $1 / 2 \mathrm{Fe}$ EDTA), supplemented with 2,4-D (2.2 $\left.\mathrm{mg} \mathrm{L}^{-1}\right)$, zeatin $\left(0.22 \mathrm{mg} \mathrm{L}^{-1}\right)$, sucrose $\left(3 \mathrm{~g} \mathrm{~L}^{-1}\right)$, ascorbic acid (10 $\left.\mathrm{mg} \mathrm{L}^{-1}\right)$ and Phytagel $\left(0.2 \mathrm{~g} \mathrm{~L}^{-1}\right)$, and cultured in an orbital shaker (100 rpm) in the dark, during three months. Half of the volume of ME2 medium was changed every week.

For embryo induction, $10 \mathrm{~mL}$ of packed cells were used ( $0.5 \mathrm{~mL} /$ Petri dish with $10 \mathrm{~mL}$ of ME3 medium). ME3 medium consisted of SH salts (Schenk \& Hildebrandt, 1972) supplemented with biotin (1.0 $\left.\mathrm{mg} \mathrm{L}^{-1}\right)$, glutamin (10 $\left.\mathrm{mg} \mathrm{L}^{-1}\right)$, prolin (2.3 $\left.\mathrm{mg} \mathrm{L}^{-1}\right)$, malt extract (400 mg L $\left.{ }^{-1}\right)$, NAA (0.204 mg L-1), Zeatin $\left(0.44 \mathrm{mg} \mathrm{L}^{-1}\right)$, Kinetin $\left(1.8 \mathrm{mg} \mathrm{L}^{-1}\right)$, 2ip $\left(0.14 \mathrm{mg} \mathrm{L}^{-1}\right)$, sucrose (44.5 g L-1), lactose (10.5 $\left.\mathrm{g} \mathrm{L}^{-1}\right)$ and Phytagel $\left(0.2 \mathrm{~g} \mathrm{~L}^{-1}\right)$. The cells were inoculated on a sterilized filter paper support, and cultivated in the dark for three months with a change to fresh medium every 30 days. After somatic embryo development, calluses were transferred to ME4 medium: MS salts supplemented with Morel vitamins (Morel \& Weatmore, 1951), BAP (0.045 $\left.\mathrm{mg} \mathrm{L}^{-1}\right)$, IAA $\left(0.205 \mathrm{mg} \mathrm{L}^{-1}\right)$, sucrose $\left(3 \mathrm{~g} \mathrm{~L}^{-1}\right)$ and Phytagel $\left(0.2 \mathrm{mg} \mathrm{L}^{-1}\right)$; and cultivated in BOD with photoperiod of 16 hours to convert embryos into plants.

The regenerated plants were transferred to the micropropagation medium (MM), which consisted of MS salts supplemented with BAP $\left(5.0 \mathrm{mg} \mathrm{L}^{-1}\right)$, sucrose $\left(3 \mathrm{~g} \mathrm{~L}^{-1}\right)$, Phytagel $\left(2 \mathrm{~g} \mathrm{~L}^{-1}\right)$. Part of the rooted material was transferred to a substrate and kept in an acclimatized glass house. Regenerated plants were maintained in a greenhouse to identify somaclonal variants. The entire regeneration process was performed twice, in order to evaluate the effect of aging on embryogenic viability of the cell suspension; the only difference was that cell suspension of the second experiment was six months older than that used in the first experiment.

For histological analysis, the embryogenic cell suspension was fixed in glutaraldehyde solution 
$2 \%(\mathrm{v} / \mathrm{v})$ with paraformaldehyde $0.5 \%$ in a sodium cacodilato buffer $(0.1 \mathrm{M}, \mathrm{pH}$ 7.2). The cell suspension was mixed with agar solution 4\% and dropped in Petri dishes. A packed of cell suspension was incubated in ice for 5 minutes, fixed with osmium tetroxide solution $1 \%$ in sodium cacodilato buffer, and incubated overnight (uranila acetate 2.5\%). After incubation, the blocked material was dehydrated in acetone and embedded in Epon 812 resin overnight. Sections of $0.4 \mathrm{~mm}$ were stained with $1 \%$ toluidine blue in $1 \%$ borate, and examined in light microscope.

After the establishment of somatic embryogenesis and plant regeneration protocols, some embryogenic calluses from cell suspension of banana cv. Maçã were bombarded with plasmid constructs, containing the gene for kanamycin resistance and the gus-A gene for $\beta$-glucoronidase. Ten Petri dishes were used containing $0.5 \mathrm{~mL}$ of packed cell suspension for each plasmid construction. The following constructs were used: pBI426 (70S promoter, uid-A/neo), pFF19 (70S promoter, uid-A) and pCAMBIA1303 (35S promoter, uid-A, Hygromycin). The DNA of each plasmid construction was isolated from the Escherichia coli DH5 $\alpha$ strain by alkaline lysis, and purified by polyethylene glycol precipitation (Concert kit; Invitrogen). Tungsten particles were prepared using $5 \mu \mathrm{L}$ of DNA ( 1 ng DNA $\left.\mu \mathrm{L}^{-1}\right), 20 \mu \mathrm{L}$ of spermidine and $50 \mu \mathrm{L}$ of $\mathrm{CaCl}_{2}$. All solutions were kept on ice. Calluses were placed $9 \mathrm{~cm}$ from the point of particle discharge, done with 1,100 psi in helium-driven particle gun for plant transformation.

After five days, part of the bombarded cells was incubated in a buffer containing $100 \mathrm{mM}$ sodium phosphate ( $\mathrm{pH} 7.0), 50 \mathrm{mM}$ ascorbate, and $1 \mathrm{mM}$ 5-bromo-4-chloro-3indolyl $\beta$ - $\delta$-glucoronide (x-glu), overnight at $37^{\circ} \mathrm{C}$.

One week after bombardment, embryogenic cells, including nonbombarded controls, were subcultured on embryogenic medium containing $100 \mathrm{mg} \mathrm{L}^{-1}$ kanamycin. Calluses were kept in the dark on embryo induction media (ME3) and subculturing to fresh media every 30 days. After initial embryo development, calluses were transferred to regeneration media (ME4) under light for plantlet growth induction.

\section{Results and Discussion}

During the first two weeks of culture in medium ME1, isolated immature male flower bracts developed necrosis. Callus formation was observed under some bracts after two months of culture initiation. Approximately $80 \%$ of the explants originated callus tissues. As Arnold et al. (2002) suggested, it is usually easy to distinguish between embryogenic and nonembryogenic calluses on the base of their morphology and color. Using their definition, $40 \%$ of banana calluses (type I) showed embryogenic characteristics such as: nonfriable, compact and yellow color (Figure $1 \mathrm{~A}$ ), but $60 \%$ of calluses (type II) had nonembryogenic characteristics (friable and white) (Figure $1 \mathrm{~B}$ ).

Both callus types were excised from the mother tissue and transferred to ME2 liquid medium. After three months, cell suspensions were established from both types. The cell shape depended completely upon the callus type. Cell suspension from callus type I exhibited small clusters of cells, which showed dense cytoplasms with small vacuoles and starch reserves in the form of small starch grains (Figure $1 \mathrm{C}$ ). Cell suspension from type II callus showed individual elongated cells (no clusters), with vacuolated cytoplasms and few starch reserves (Figure 1D). According to Dhed'a et al. (1991), elongated and highly vacuolated cells apparently originate from the nonmeristematic tissue, while oval cells, containing large starch granules, originated from the meristematic tissue.

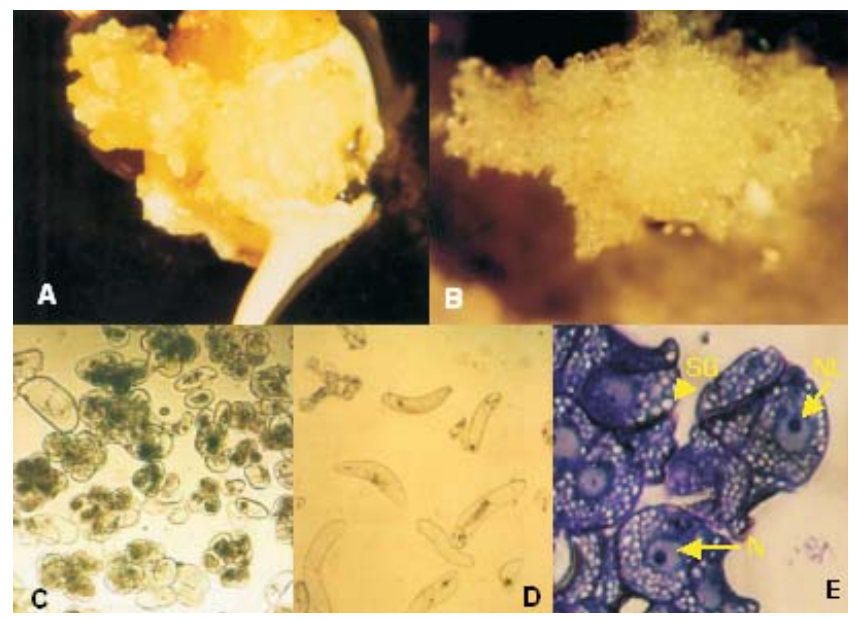

Figure 1. Callus types and cell suspension of banana cv. Maçã. A: embryogenic callus (type I); B: embryogenic cell suspension formed by callus type I; C: nonembryogenic callus (type II); D: nonembryogenic cell suspension; E: histological preparation of embryogenic cell suspension (SG - starch grains; NL - nucleolus; $\mathrm{N}$ - nucleus). 
The embryogenic cell suspension, originated from callus type I, contained clusters of small tightly packed cells with dense cytoplasms, a relatively large nuclei, very dense nucleoli and tiny starch and protein grains (Figure $1 \mathrm{E}$ ). These characteristics are generally associated with morphogenetic competence and characterize embryogenic cell masses (Dhed'a et al., 1991; Alemanno et al., 1996). Cell aggregates similar to those found in cell suspension type I were described before in other species, such as corn (Emons \& Kieft, 1992) and wheat (Tabaeizadeh \& Campeau, 1992). These cell clusters were called "proembryogenic masses" (Georget et al., 2000) and indicate that cell suspension has embryogenic potential. The cell suspension has a thick consistency when the cell concentration is high. Kosky et al. (2002) observed a similar result. However, regeneration induction is necessary to confirm the embryogenic potential.

Plant regeneration was observed only with the cell suspension originated from callus type I. This result was expected from embryogenic cells with characteristics described previously. According to Arnold et al. (2002), the competence for embryogenic induction may be the result of the varying auxin sensitivity of these cells. These authors also suggested that the developmental response pattern of cultured tissue is epigenetically determined and influenced by the stage of plant development and the nature of the explant. The banana cell suspension observed was characterized by a slow development of cell clusters, making the plant regeneration time-consuming. According to Georget et al. (2000), this is a common feature of many banana cell culture protocols. These authors suggested that signals, as cellular density, could participate in the development type of aggregates.

Embryogenic callus development was observed after one month of cell culture in semi-solid medium (Figure $2 \mathrm{~A}$ ). All embryos emerged from callus tissue, and no secondary somatic embryo formation was observed. Cronauer-Mitra \& Krikorian (1988) described similar results. In the first step of plant regeneration, embryogenic globular compact structures were identified, after three months of culture, in ME2 medium (Figure 2 B). The development of these globular structures originated an apical invaginated area, corresponding to the cotyledonary stage of zygotic embryos. Differences in somatic stages of embryogenesis were observed on the callus surface.

During the regeneration time, the maximum number of regenerated plants was observed between 45 and
60 days of culture, in two experiments. In the first experiment (I), 401 plants were regenerated from approximately $10 \mathrm{~mL}$ of packed embryogenic cells. In the second experiment (II), using the same initial cell volume, 399 plants were regenerated from a cell suspension that was six months older than that of the first experiment (Table 1). In most crops, the embryogenic potential decreases with extended culture and is eventually lost (Arnold et al., 2002). The germination of embryos initiated with shoot development and leaf differenciation (Figure $2 \mathrm{C}$ and $\mathrm{D}$ ), followed by the elongation of the primary roots and the formation of adventitious roots (Figure 2 E). After embryo convertion, no embryo development was observed in embryogenic callus.

Some plants from both experiments showed slower development, when compared with plants of the same age regenerated from shoot tips of banana cv. Maçã. These growth differences were also observed, when the plants were transferred to the rooting medium (Figure $3 \mathrm{~A}$ ). After acclimatization, these plants continued to show low height (Figure $3 \mathrm{~B}$ and $\mathrm{C}$ ), probably as a result of somaclonal variation, often described in plants regenerated from cell culture. Arnold et al. (2002) suggested that mutation is the origin of this kind of off-type, because mutations could affect genes that play a more direct role in plant growth and

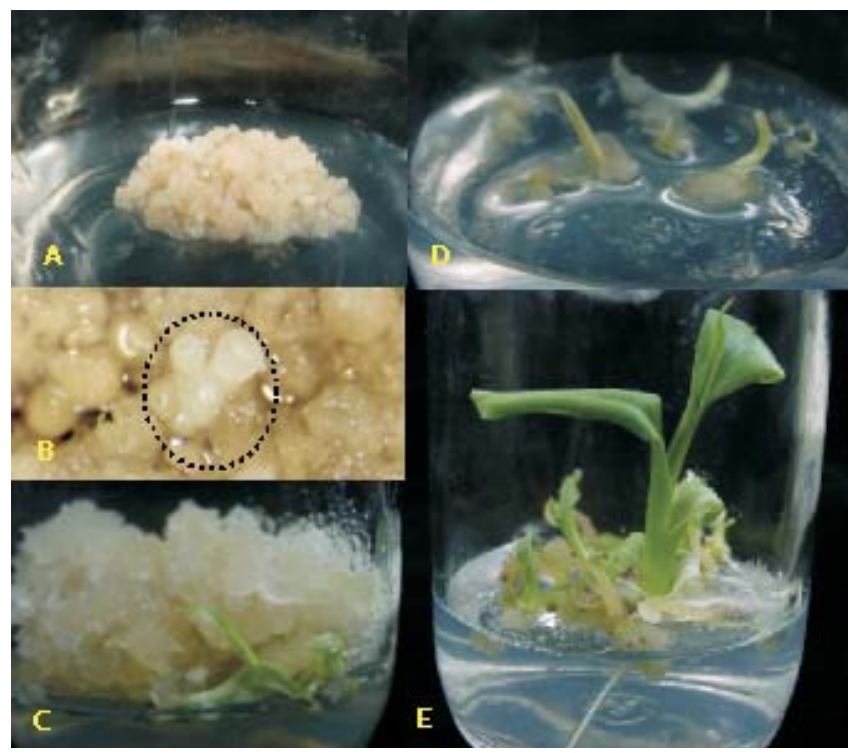

Figure 2. Somatic embryogenesis of banana cv. Maçã. A: embryogenic callus from cell suspension; B: somatic embryos; C and D: embryo plant conversion; E: plants from embryogenic callus. 
development. Only mature embryos with a normal morphology, and which have accumulated enough storage material, and acquired desiccation tolerance at the end of maturation, could develop into normal plants. Somaclonal variation is a problem caused, in many cases, either by a prolonged callus phase and the use of 2,4-D (Arnold et al., 2002).

There is no information concerning the exact ontogenesis of these plants from callus. However, it may be suggested that they originated from somatic embryogenesis, because the sequential steps observed here are similar to those described for other monocot species (Conceição et al., 1998).

Table 1. Regenerated plants obtained from cell suspension with different culture period.

\begin{tabular}{|c|c|c|c|c|c|c|}
\hline \multirow{2}{*}{\multicolumn{2}{|c|}{ Experiment $^{(1)}$}} & \multicolumn{5}{|c|}{ Culture period (days) } \\
\hline & & 15 & 30 & 45 & 60 & 90 \\
\hline I & & 0 & 123 & 401 & 401 & 401 \\
\hline II & & 0 & 86 & 398 & 399 & 399 \\
\hline \multirow[t]{2}{*}{ III } & pBI426 & 0 & 0 & 7 & 18 & 29 \\
\hline & pCAMBIA & 0 & 0 & 7 & 18 & 29 \\
\hline
\end{tabular}

(1)Experiment I used a recent developed cell suspension; experiment II used a six months older cell suspension culture; experiment III used a bombarded cell suspension.

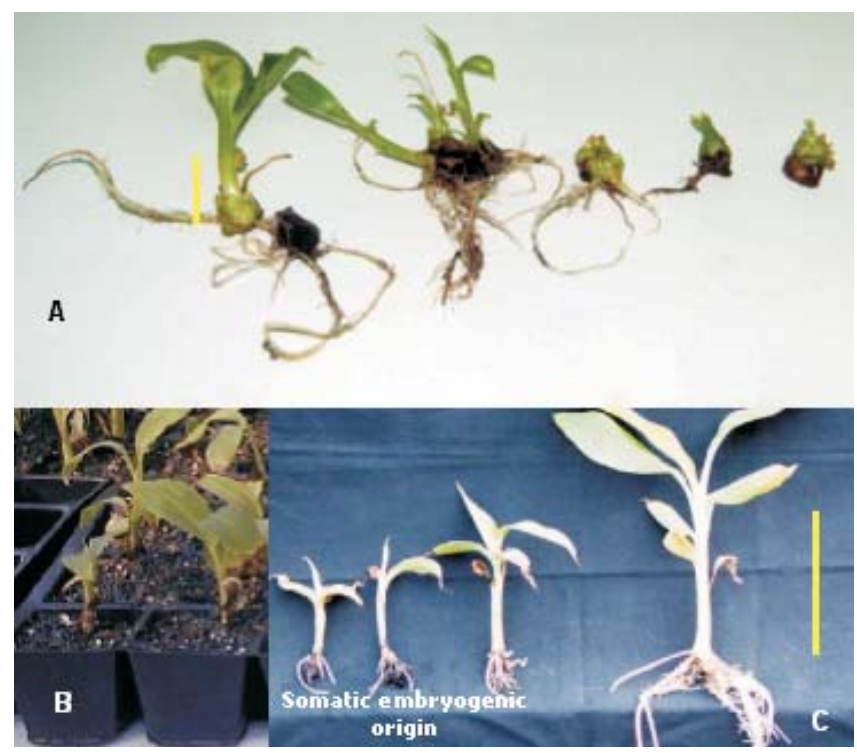

Figure 3. Aspects of banana cv. Maçã plants obtained from somatic embryogenesis. A: rooted plants regenerated from cell suspension with one month (yellow bar $=1.5 \mathrm{~cm}$ ); B: acclimatized plants regenerated from cell suspension with size differences; C: acclimatized plants regenerated from cell suspension and from shoot tips with the same age (yellow bar $=10 \mathrm{~cm})$.
Transient expression was confirmed by GUS histochemical assay five days after bombardment. All constructs were GUS-positive. Similar levels of expression where observed, when the maize ubiquitin or the duplicated 35S CaMV promoter were used (Figure 4). Embryogenic structures were observed six months after bombardment, and plant regeneration was observed in all materials three months after transferring to light conditions. The number of plants obtained from bombarded material was inferior to nonbombarded embryogenic cells. The best result was observed with pBI426, in which 29 plants were regenerated, while only two plants were regenerated from callus bombarded with pCAMBIA1303. The reduction of the regenerating potential has been described before in bombarded banana cell suspension (Becker et al., 2000).

These results can be an effect of the antibiotic selection and bombardment treatment. Becker et al. (2000) reported that selection of bombarded embryogenic cell suspension of Bluggoe (Musa ssp. ABB group), with geneticin, allowed transgenic embryo transformation but interfered with embryo germination. This inhibitory effect has also been previously reported in other crops (Yao et al., 1995; Bretagnesagnard \& Chupeau, 1996). Shock waves and sound waves, promoted by the biobalistic equipment, can cause damage to the explant target at the cellular level, as membranes disrupt, thus interfering with the regenerative process (Russel et al., 1992).

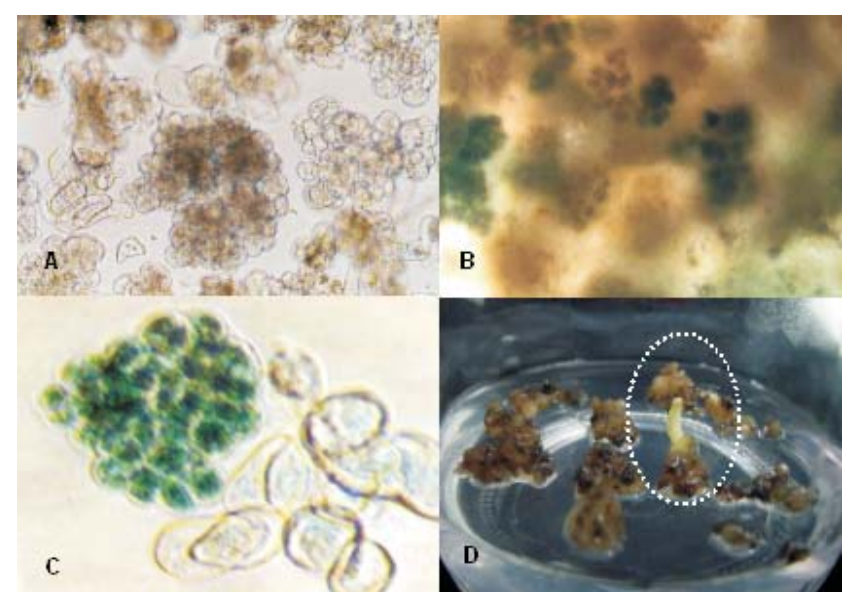

Figure 4. Aspect of cell suspension transformation of banana cv. Maçã. A: nontransformed cell suspension; B and C: positive GUS test in embryogenic cell cluster; D: somatic embryogenesis of callus formed from bombarded cell suspension. 


\section{Conclusions}

1. Callus induction from male inflorescence, of Brazilian banana cultivar Maçã (Silk type, AAB group), is an efficient method for embryogenic callus production and plant regeneration.

2. Callus characteristics, such as yellow color and nonfriability, are related to embryogenic potential of cell suspensions.

3. Particle bombardment of cell suspension reduces plant regeneration efficiency.

\section{Acknowledgements}

To Fundação de Amparo à Pesquisa do Estado de São Paulo (Fapesp), for financial support.

\section{References}

ALEMANNO, L.; BERTHOULY, M.; MICHAUX-FERRIÈRE, N. Histology of somatic embryogenesis from floral tissues cocoa. Plant Cell, Tissue and Organ Culture, v.46, p.187-194, 1996.

ARNOLD, S.V.; SABALA, I.; BOZHKOV, P.; DYACHOK, J.; FILONOVA, L. Developmental pathways of somatic embryogenesis. Plant Cell, Tissue and Organ Culture, v.69, p.233-249, 2002.

BECKER, D.K.; DUGDALE, B.; SMITH, M.K.; HARDING, R.M.; DALE, J.L. Genetic transformation of Cavendish banana (Musa spp. AAA group) cv. Grand nain via microprojectile bombardment. Plant Cell Reports, v.19, p.229-234, 2000.

BRETAGNESAGNARD, B.; CHUPEAU, Y. Selection of transgenic flax plants facilitated by spectinomycin. Transgenic Research, v.5, p.131-137, 1996.

CONCEIÇÃO, A. da S.; MATSUMOTO, K.; BAKRY, F.; BERNDSOUZA, R.B. Plant regeneration from long-term callus culture of AAA-group dessert banana. Pesquisa Agropecuária Brasileira, v.33, p.1291-1296, 1998.

CÔTE, E.X.; DOMERGUE, R.; MONMARSON， J.; SCHWENDIMAN, J.; TEISSON, C.; ESCALANT, J.V. Embryogenic cell suspensions from the male flower of Musa AAA cv. Grand nain. Physiologia Plantarum, v.97, p.285-290, 1996.

CRONAUER-MITRA, S.S.; KRIKORIAN, A.D. Plant regeneration via somatic embryogenesis in the seed diploid banana Musa ornata Roxb. Plant Cell Reports, v.7, p.23-25, 1988.

DHED’A, D.; DUMORTIER, F.; PANIS, B.; VUYLSTEKE, D.; LANGHE, E. de. Plant regeneration in cell suspension cultures of cooking banana cv. Bluggoe. Fruits, v.46, p.125-135, 1991.

EMONS, A.M.C.; KIEFT, H. Histological comparison of single somatic embryos of maize from suspension culture with somatic embryos attached to callus cells. Plant Cell Report, v.11, p.122-125, 1992.
ESCALANT, J.V.; TEISSON, C.; CÔTE, F. Amplified somatic embryogenesis from male flowers of triploid banana and plantain cultivars (Musa spp.). In Vitro Cell Developmental Biology, v.30, p.181-186, 1994.

FAO. FAOSTAT statistical database. Rome, 2001.

GEORGET, F.; DOMERGUE, R.; FERRIÈRE, N.; CÔTE, F.X. Morphohistological study of the different constituents of banana (Musa AAA, cv. Grand nain) embryogenic cell suspension. Plant Cell Reports, v.19, p.748-754, 2000.

KHALIL, S.M.; CHEAH, K.T.; PEREZ, E.A.; GASKILL, D.A.; HU, J.S. Regeneration of banana (Musa spp. AAB cv. Dwarf Brazilian) via secondary somatic embryogenesis. Plant Cell Report, v.20, p.1128-1134, 2002.

KOSKY, R.G.; SILVA, M. de E.F.; PÉREZ, L.P.; GILLIARD, T.; MARTINEZ, F.B.; VEJA, M.R.; MILIAN, M.C.; MENDOZA, E.Q. Somatic embryogenesis of the banana hybrid cultivar FHIA-18 (AAAB) in liquid medium and scaled-up in bioreactor. Plant Cell, Tissue and Organ Culture, v.68, p.21-26, 2002.

MOREL, G.; WETMORE, R.H. Tissue culture of monocotyledons. American Journal of Botany, v.38, p.138-140, 1951.

MURASHIGE, T.; SKOOG, F. A revised media for rapid growth and bioassays with tobacco tissue culture. Physiologia Plantarum, v.15, p.473-497, 1962.

NAVARRO, C.; ESCOBEDO, R.M.; MAYO, A. In vitro plant regeneration from embryogenic cultures of a diploid and a triploid, Cavendish banana. Plant Cell, Tissue and Organ Culture, v.51, p.17-25, 1997.

NOVAK, F.J.; AFIA, R.; VAN DUREN, M.; PERSA-DALLOS, M.; CONGER, B.V.; XIAO-LANG, T. Somatic embryogenesis and plant regeneration in suspension cultures of dessert (AA and AAA) and cooking (ABB) bananas (Musa spp.). Biotechnology, v.7, p.154159, 1989

PANIS, B.; SWENNEN, R. Embryogenic Musa plant cell cultures: current and future applications. Infomusa, v.2, p.3-6, 1993.

RUSSELL, J.A.; ROY, M.K.; SANFOR, J.C. Physical trauma and tungsten toxicity reduce the efficiency of biobalistic transformation. Plant Physiology, v.98, p.1050-1056, 1992.

SAGI, L.; PANIS, B.; REMI, S.; SCHOOFS, H.; SMET, K.D.; SWENNEN, R.; CAMMUE, B.P.A. Genetic transformation of banana and plantain (Musa spp.) via particle bombardment. Bio/ Technology, v.13, p.481-485, 1995.

SASSON, A. Importance of tropical and subtropical horticulture, future prospects of biotechnology in tropical and subtropical horticulture species. Acta Horticulturae, v.460, p.12-26, 1997.

SCHENK, R.U.; HILDEBRANDT, A.C. Medium and techniques for induction and growth of monocotyledonous and dicotyledonous plant cell cultures. Canadian Journal of Botany, v.50, p.199-204, 1972.

SHEPHERD, K. Banana breeding - past and present. Acta Horticulturae, v.196, p.37-43, 1987.

TABAEIZADEH, Z.; CAMPEAU, N. Embryogenic cell suspension of Triticum aestivum $\mathrm{x}$ Leymus angustus $\mathrm{F}_{1}$ hybrids: characterization and plant regeneration. Plant Cell Report, v.11, p.81-85, 1992.

YAO, J.L.; COHEN, D.; ATKINSON, R.; RICHARDSON, K.; MORRIS, B. Regeneration of transgenic plants from the commercial apple cultivar Royal Gala. Plant Cell Report, v.14, p.407-412, 1995.

Received on June 28, 2004 and accepted on March 29, 2005 